\title{
Hepatitis herpética en paciente hematológico
}

\author{
J. Ortiz, F. González San Martín¹, O. Bengoechea, F. Geijo y A. Bullón \\ Servicios de Anatomía Patológica y ${ }^{I}$ Gastroenterología. Hospital Universitario de Salamanca
}

\section{CASO CLÍNICO}

Varón de 16 años de edad, en tratamiento quimioterápico por enfermedad de Hodgkin de carácter recidivante. En el curso de dicho tratamiento, el paciente mostró signos de hemorragia digestiva (melenas), acompañados de una intensa elevación de las transaminasas y una importante alteración en las pruebas de coagulación sanguínea (actividad de protombina). Dicho paciente falleció a los pocos días, por un cuadro de insuficiencia hepática aguda, con signos de encefalopatía y hemorragia digestiva masiva.

En la necropsia se observó un daño hepático difuso, acompañado de lesiones focales en el tercio inferior del esófago. El estudio histológico demostró, en ambos órganos, una lesión inflamatoria de carácter necrotizante, evidenciándose cambios citopáticos propios de infección herpética, consistentes en imágenes de multinucleación y presencia de cuerpos de Cowdry tipo A (Figs. 1 y 2).

\section{COMENTARIO}

Las modernas terapias antineoplásicas muestran en muchos casos, como efecto secundario poco deseable, una capacidad inmunosupresora capaz de favorecer infecciones por gérmenes oportunistas. Entre estos gérmenes oportunistas, los virus ocupan un puesto principal. En nuestro caso nos encontramos con un paciente que padecía una enfermedad anergizante (linfoma de Hodgkin) y que fue sometido a quimioterapia. Esta situación claramente inmunosupresora abrió la puerta a una infección herpética, reconocible por los efectos citopáticos descritos para los virus del herpes $(1,2)$. Dicha infección ocasionó una hepatitis fulminante, gravísima situación clínica, poco frecuente en nuestra diaria labor asistencial, pero claramente descrita y recogida en la literatura médica $(3,4)$. La presencia si-

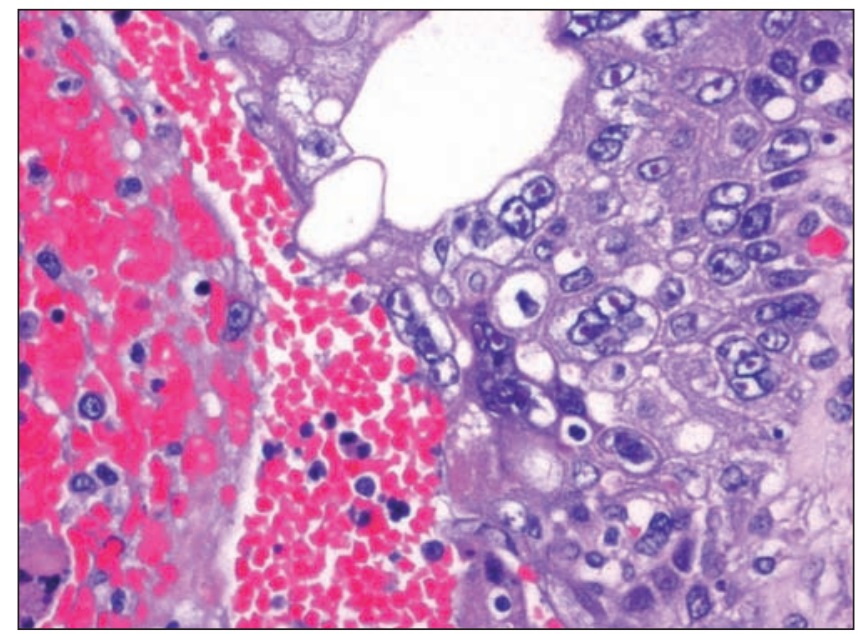

Fig. 1. Esofagitis herpética: lesiones hemorrágico-necrotizantes intraepiteliales con presencia de células multinucleadas y cuerpos de inclusión (HE x 200).



Fig. 2. Hepatitis herpética: inflamación hepática necrotizante con presencia de cambios citopáticos, análogos a los observados en esófago. 
multánea de lesiones en esófago nos hizo pensar en una infección primaria esofágica con posterior diseminación hepática, como teoría etiopatogénica más verosímil. De igual modo, la afectación esofágica nos llevó a considerar al herpes virus tipo I como agente etiológico más probable, si bien la ausencia de estudios bacteriológicos no nos ha permitido confirmar esta apreciación (5).

\section{BIBLIOGRAFÍA}

1. Lee B, Caddy G. A rare cause of dysphagia: Herpes simplex esophagitis. World J Gastroenterol 2007; 13 (19): $2756-7$.

2. Friedberg MA, Schwartz JC, Feinman MC, Pilkerton AR, Barth WF, Perman KI. Systemic herpetic infection diagnosed by retinal biopsy. Ophthalmic Surg 1993; 24 (3): 203-5.

3. Norvell JP, Blei AT, Jovanovic BD, Levitsky J. Herpes simplex virus hepatitis: An analysis of the published literature and institutional cases. Liver Transpl 2007; 13 (10): 1428-34.

4. Ichai P, Alfonso AM, Sebagh M, González ME, Codés L, Azoulay D, et al. Herpes simplex virus-associated acute liver failure: A difficult diagnosis with a poor prognosis. Liver Transpl 2005; 11 (12): 1550-5.

5. Itoh T, Takahashi T, Kusaka K, Kawaura K, Nakagawa Y, Yamakawa J, Kanda T. Herpes simplex esophagitis from 1307 autopsy cases. J Gastroenterol Hepatol 2003; 18 (12): 1407-11. 